\title{
Composition and corrosion phases of Etruscan Bronzes from Villanovan Age
}

\author{
G Festa ${ }^{1}$, P A Caroppi ${ }^{1}$, A Filabozzi ${ }^{1}$, C Andreani ${ }^{1}$, \\ M L Arancio ${ }^{2}$, R Triolo ${ }^{3}$, F Lo Celso ${ }^{3}$, V Benfante $^{3}$ and S Imberti ${ }^{4}$ \\ ${ }^{1}$ Università degli Studi di Roma 'Tor Vergata' \& NAST Centre and Dipartimento di Fisica, Via Ricerca \\ Scientifica, 1, 00133 Roma, Italy \\ ${ }^{2}$ Museo Nazionale Etrusco di Villa Giulia, Roma, Italy \\ ${ }^{3}$ Università degli Studi di Palermo, Dipartimento di Chimica Fisica 'F Accascina', \\ V.le delle Scienze, 90128 Palermo, Italy \\ ${ }^{4}$ Rutherford Appleton Laboratory, ISIS Facility, Chilton, Didcot, UK
}

Received 15 July 2007, in final form 19 October 2007

Published 30 January 2008

Online at stacks.iop.org/MST/19/034004

\begin{abstract}
A neutron diffraction (ND) and neutron tomography (NT) study of laminated ancient bronzes was performed at the ISIS (Rutherford Appleton Laboratory, UK) neutron source and at the BENSC reactor (Hahn-Meitner Institut, Germany). The samples are part of an 8th century BC Etruscan collection discovered in the necropolises of Osteria-Poggio Mengarelli and Cavalupo in the Vulci area (Viterbo, Italy). The study allowed us to derive-in a totally non-destructive manner-information related to the main composition of the objects, possible presence of alterations and their nature, crusts and inclusions, as well as structure of the bulk. The presence of some components is linked to a variety of questions such as the correct determination of the historical and cultural timeframe, place and method of production, technologies adopted and conditions for restoration and preservation. Moreover, the data analysis of corrosion products provides information about the past environments and the physical/chemical events that transformed the objects into a partially corroded matrix.
\end{abstract}

Keywords: neutron diffraction, neutron tomography, ancient bronzes, corrosion, chemical environment, working methods, structure of the bulk

(Some figures in this article are in colour only in the electronic version)

\section{Introduction}

Since early ages copper has been known to mankind. Already in the Bronze Age (3000-1300 BC) people were using it to craft tools and weapons thanks to its malleability and ductility. Thus copper is one of the most important metals and together with its alloys, brass and bronze, has been extensively used in artistic, structural and architectural applications. On exposure to natural environments copper surfaces develop a layer of corrosion products, namely a patina. The formation of a copper patina is a sequential process with the initial formation of a thin layer of cuprite $\left(\mathrm{Cu}_{2} \mathrm{O}\right)$. This layer causes the copper surface to lose its metallic colour and turn dull brown after a few days or months, depending on exposure conditions. After several years of exposure, other phases are formed in the corrosion layer. In rural and little polluted urban atmospheres, the patina mainly consists of copper oxides and sulphates, whereas in marine environments copper chloride is also produced [1]. Such analysis of corrosion products and patinas provides information about the past environments and the physical/chemical events that transformed the object into a partially corroded matrix.

This work presents results of non-destructive neutron diffraction (ND) and neutron tomography (NT) on 8th century BC laminated Etruscan bronzes with the aim of collecting information related to the main composition of the artefacts, the presence and nature of alterations or inclusions and the bulk structure. The experiments were performed at the ISIS spallation neutron source (UK) and at the BENSC reactor (Germany). The bronze vases, preserved at the Museo Nazionale Etrusco di Villa Giulia (Rome, Italy), are part of an Etruscan collection discovered in the necropolises of 


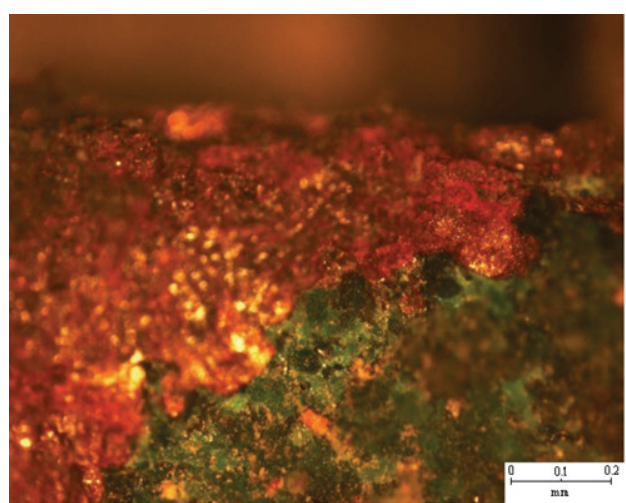

(a)

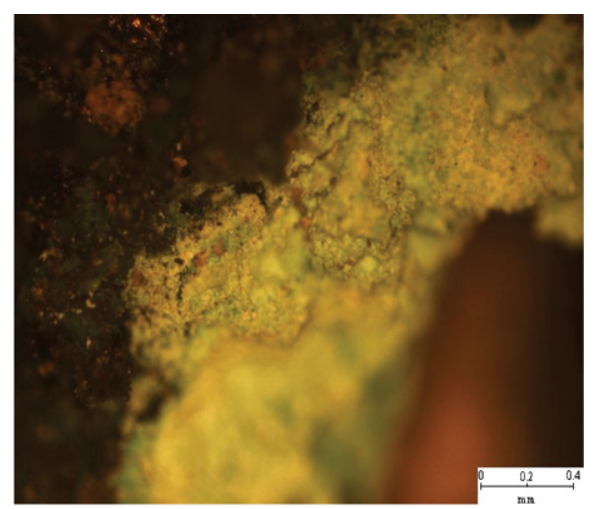

(b)

Figure 1. Micrographs of samples $5(a)$ and $3(b)$ report the images of a preliminary observation of the samples' surfaces. Enlargements are $20 \times$ and $10 \times$, respectively. Different colours can be associated with different compounds, which will be quantitatively identified in the following by the neutron diffraction analysis.

Osteria-Poggio Mengarelli and Cavalupo in the outskirts of Vulci (Viterbo, Italy).

During the first millennium BC the large area of Vulci was a site of an Etruscan community. The town development took place during the two centuries characterizing the Villanoviano period (9th-8th BC): the ancient villages slowly began to merge into rich and fortified towns [2, 3]. This was a time of large transformations and Vulci workshops had a fundamental role in the metallurgic activity of Southern Etruria. The vases were used to hold, pour or drink liquids; they were placed in the tombs to evoke the convivial ceremony held by the dominant elites [3]. In general, these ancient artefacts raise a variety of questions such as the correct determination of their historical and cultural time-frame, the place and method of production, the choice of the best treatments and conditions for restoration and preservation.

\section{Materials}

The samples, 14 fragments, were analysed with regard to chemical-phase compositions and corrosion products. Bronze is composed of copper, tin $(\mathrm{Cu}, 85-95 \%, \mathrm{Sn}, 5-15 \%)$ and small quantities of other metals. The determination of the exact copper/tin/lead relative composition provides important information on the working process and technologies adopted and, indirectly, on the authenticity of the artefacts. On the other hand, the presence of other components, like corrosion products, is linked to the past environment and to the physical and chemical events that transformed the object into a partially corroded matrix (i.e. burial environment or exposure to the atmosphere, marine conditions and laboratory environment). The atomic arrangement in the bronze alloy can be seen as the incorporation of tin into the copper crystalline structure. This does not change the crystal structure, but it expands the unit cell since tin atoms are bigger than copper ones. Evaluation of unit cell expansion provides indirectly information on the tin content and, therefore, the type of bronze [4, 5]. Some bronzes also contain lead added to the mixture of copper and tin in order to lower the melting temperature during casting. In low-tin bronzes (content of tin less than $17 \%$ by weight), typically used for casting, the lead concentrates in small globules throughout the metallic structure. These globules (typically 30-200 $\mu \mathrm{m}$ in diameter) are randomly distributed in the metallic structure.

As a preliminary observation optical microscope photomicrographs with different enlargements $(5 \times, 10 \times, 20 \times$, $50 \times$ ) of all the samples have been performed in order to examine their surface. Regions of different colours corresponding to the various patinas and corrosion phases have been observed; eventually they have been identified and quantified by ND. As an example, photo-micrographs for samples 5 and 3 are reported in figure 1 .

\section{Neutron experiments}

\subsection{Neutron diffraction measurements and results}

ND is a powerful and highly non-destructive technique for investigating the composition of archaeological metallic samples. Neutrons are highly penetrating and beams are usually large: this technique provides a reliable determination of the average composition of the whole sample. Measurements were performed on INES powder diffractometer at ISIS Spallation Source (Rutherford Appleton Laboratory, UK). This instrument is equipped with 9 detector banks, each composed of 16 squashed ${ }^{3} \mathrm{He}$ tubes with an active volume of $(100 \times 12.5 \times 2.5) \mathrm{mm}^{3}$. The wide angular range covered by the detectors $\left(11.6^{\circ}-170.6^{\circ}\right)$, together with the hot neutron beam coming from the water moderator (incident wavelength range of $0.17-3.24 \AA$ ), allows us to investigate a wide range of $d$-spacing (between $d=0.1 \AA$ and $d=16 \AA$ ) and a high resolution up to $\Delta d / d=0.002$.

Each sample was placed in a vanadium pocket positioned inside an evacuated sample chamber. The object was studied with a single sampling by using a beam size of $(4 \times 4)$ $\mathrm{cm}^{2}$; in most cases the beam area covered the whole fragment being examined, thus allowing a reliable determination of the average composition. The spectra cover a slightly different $d$-spacing range with a diverse resolution: the first bank (at highest resolution) is in back-scattering and detects the pattern in the region between $0.1 \AA$ and $1.6 \AA$. Indeed, this is the area 
Table 1. Results from ND analysis: weight percentage (wt\%) of the different compounds present in examined samples 1 to 14 is reported. The errors in calculated $\mathrm{wt} \%$ are around $1 \%$.

\begin{tabular}{|c|c|c|c|c|c|c|c|c|c|c|}
\hline No & $\begin{array}{l}\text { Bronze } \\
(\mathrm{wt} \%)\end{array}$ & $\begin{array}{l}\text { Lattice } \\
\text { parameters }(\AA)\end{array}$ & $\begin{array}{l}\mathrm{Cu} ; \mathrm{Sn}(\mathrm{wt} \%) \\
\text { in bronze }\end{array}$ & $\begin{array}{l}\mathrm{Pb} \\
(\mathrm{wt} \%)\end{array}$ & $\begin{array}{l}\text { Cuprite } \\
(\mathrm{wt} \%)\end{array}$ & $\begin{array}{l}\text { Tenorite } \\
(\mathrm{wt} \%)\end{array}$ & $\begin{array}{l}\text { Azurite } \\
(\mathrm{wt} \%)\end{array}$ & $\begin{array}{l}\text { Covellite } \\
(\mathrm{wt} \%)\end{array}$ & $\begin{array}{l}\text { Botallackite } \\
(\mathrm{wt} \%)\end{array}$ & $\begin{array}{l}\text { Nantokite } \\
(\mathrm{wt} \%)\end{array}$ \\
\hline 1 & 84.3 & $a=b=c=3.681$ & $88.5 ; 11.5$ & 3.7 & 12.0 & - & - & - & - & - \\
\hline 2 & 75.6 & $a=b=c=3.676$ & $89.4 ; 10.6$ & 2.1 & 22.3 & - & - & - & - & - \\
\hline 3 & 34.7 & $a=b=c=3.658$ & $92.3 ; 7.7$ & - & 60.0 & - & 5.3 & - & - & - \\
\hline 4 & 80.1 & $a=b=c=3.678$ & $89.1 ; 10.9$ & 2.9 & 17.0 & - & - & - & - & - \\
\hline 5 & 76.3 & $a=b=c=3.676$ & $89.3 ; 10.7$ & 0.8 & 8.1 & - & - & 14.8 & - & - \\
\hline 6 & 75.2 & $a=b=c=3.666$ & $91.0 ; 9.0$ & 1.4 & 20.0 & 1.8 & - & - & - & 1.6 \\
\hline 7 & 77.5 & $a=b=c=3.674$ & $89.7 ; 10.3$ & 1.9 & 18.8 & 1.8 & - & - & - & - \\
\hline \multirow[t]{2}{*}{8} & 70.0 & $a=b=c=3.657$ & $92.6 ; 7.4$ & - & 1.4 & - & - & 6.5 & - & - \\
\hline & 22.1 & $a=b=c=3.689$ & $87.2 ; 12.8$ & - & - & - & - & - & - & - \\
\hline 9 & - & - & - & 8.9 & 91.1 & - & - & - & - & - \\
\hline 10 & - & - & - & 5.9 & 49.0 & 8.9 & - & 31.4 & 4.8 & - \\
\hline 11 & 60.9 & $a=b=c=3.673$ & $89.8 ; 10.2$ & 1.7 & 33.7 & 2.2 & - & - & - & 1.5 \\
\hline 12 & 89.4 & $a=b=c=3.684$ & $88.0 ; 12.0$ & 0.3 & 10.3 & - & - & - & - & - \\
\hline 13 & 74.5 & $a=b=c=3.663$ & $91.6 ; 8.4$ & 1.5 & 21.6 & - & - & - & - & 2.4 \\
\hline 14 & 88.8 & $a=b=c=3.694$ & $86.3 ; 13.7$ & 1.1 & 10.1 & - & - & - & - & - \\
\hline
\end{tabular}

with the highest density of peaks. The last bank, in forward scattering, covers the high- $d$ region; here only a few peaks are present but these are the most important for the identification of the phases. The data have been normalized to the number of counts (through the incident monitor) and have been divided by a vanadium rod spectrum in order to account for the detectors' efficiency. Typical spectra with counts reported as a function of the $d$-spacing are shown in figures $2(a)$ and $(b)$ together with the best fits obtained.

Quantitative phase analysis is based on the principle that on the one hand each phase exhibits a unique set of diffraction peaks, on the other hand the intensity of each peak of a particular phase is proportional to the phase weight-fraction and the measured diffraction pattern is the simple sum of all single-phase patterns.

Data for each sample have been fitted with the commercial GSAS software (with the graphical interface EXPGUI) based on the established Rietveld analysis method for quantitative phase assessment which yields phase fractions of the main phases [6, 7]. Some of the phases have been retrieved through The United Kingdom Chemical Database Service [8]. Results of the Rietveld analysis are shown and compared in table 1. Figures 3(a) and $(b)$ also report some results of ND analysis shown in table 1. Figure 3(a) represents as an histogram the number of samples where a given weight percentage of bronze has been detected, figure $3(b)$ the number of samples where a given weight percentage of $\mathrm{Cu}$ in the bronze alloy has been detected. It appears that $60-95 \%$ of the total artifacts weight (see figure $3(a)$ ) is made of uncorroded alloy, i.e. bronze; this bronze presents a content of $\mathrm{Cu}=90 \pm 4 \%$ (see figure $3(b)$ ), which is typical of low tin ancient bronzes. This figure supports the authenticity of such investigated samples.

Recent studies [4, 5] have shown that peak widths, derived from Gaussian fits of ND data, are related to thermal-mechanical treatments. The conclusions drawn in these papers, based on experiments performed on standard samples, relate the relative peak widths $\Delta d / d$ trend and the different working treatments, such as hammering, raw casting,

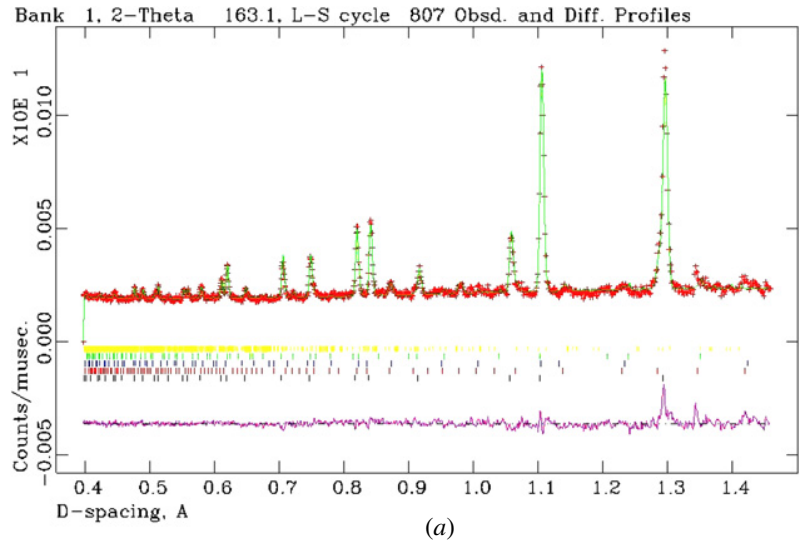

Vulci 8 Poggio Mengarelli

Bank 3. 2-Theta 127.1. L-S cycle 1016 Obsd. and Diff. Profiles

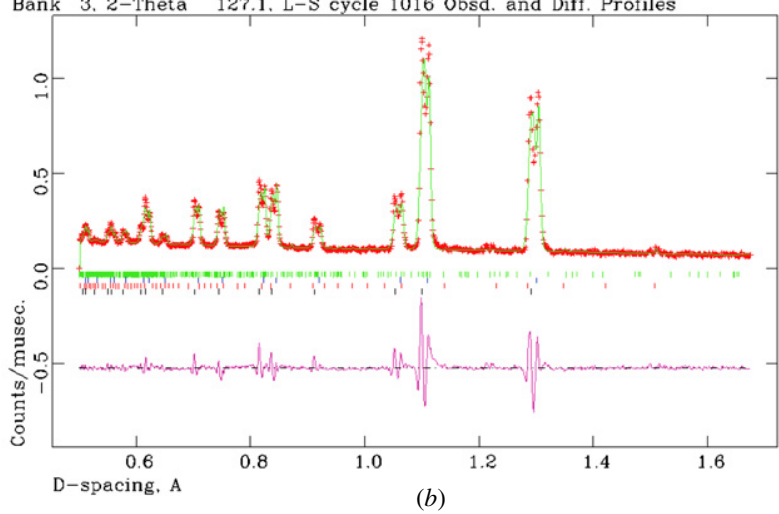

Figure 2. Typical spectra are reported as normalized number of counts as a function of $d$-spacing. Best fit of data is also shown, with the peak position of the different components, and residue is reported in violet. (a) Sample 6, detector bank no. 1 at $2 \theta=163.0^{\circ}$. Components: yellow $=$ bronze $(\mathrm{Cu} / \mathrm{Sn})$, green $=$ cuprite $\left(\mathrm{Cu}_{2} \mathrm{O}\right)$, blue $=$ lead, black $=$ tenorite $(\mathrm{CuO})$, red $=$ nantokite $(\mathrm{CuCl})$; (b) sample 8 , detector bank no. 1 at $2 \theta=127.1^{\circ}$. Components: black $=$ bronze $1(\mathrm{Cu} / \mathrm{Sn})$, blue $=$ bronze $2(\mathrm{Cu} / \mathrm{Sn})$, red $=$ cuprite $\left(\mathrm{Cu}_{2} \mathrm{O}\right)$, green $=$ covellite $(\mathrm{CuS})$. It presents double bronze peaks, corresponding to different percentages of tin in the alloy: this sample is composed of two distinct parts, not coming from the same casting. 
Table 2. Comparison between results from ND analysis and NT (measurements performed in high-resolution-position set-up) analysis.

\begin{tabular}{|c|c|c|c|c|c|c|c|}
\hline \multicolumn{8}{|c|}{ No } \\
\hline 7 & $\begin{array}{l}\text { Phases } \\
\text { Component peak }\left(\mathrm{cm}^{-1}\right)\end{array}$ & $\begin{array}{l}\text { Tenorite } \\
?\end{array}$ & $\begin{array}{l}\text { Lead } \\
0.54\end{array}$ & $\begin{array}{l}\text { Bronze } \\
0.9\end{array}$ & & $\begin{array}{l}\text { Cuprite } \\
1.12\end{array}$ & \\
\hline 8 & $\begin{array}{l}\text { Phases } \\
\text { Component peak }\left(\mathrm{cm}^{-1}\right)\end{array}$ & & Lead & $\begin{array}{l}\text { Bronze } \\
0.88\end{array}$ & $\begin{array}{l}\text { Bronze } 2 \\
0.77\end{array}$ & Cuprite & $\begin{array}{l}\text { Covellite } \\
1.86\end{array}$ \\
\hline 12 & $\begin{array}{l}\text { Phases } \\
\text { Component peak }\left(\mathrm{cm}^{-1}\right)\end{array}$ & & $\begin{array}{l}\text { Lead } \\
0.52\end{array}$ & $\begin{array}{l}\text { Bronze } \\
0.94\end{array}$ & & $\begin{array}{l}\text { Cuprite } \\
1.22\end{array}$ & \\
\hline 14 & $\begin{array}{l}\text { Phases } \\
\text { Component peak }\left(\mathrm{cm}^{-1}\right)\end{array}$ & & $\begin{array}{l}\text { Lead } \\
0.52\end{array}$ & $\begin{array}{l}\text { Bronze } \\
0.88\end{array}$ & & $\begin{array}{l}\text { Cuprite } \\
1.07\end{array}$ & \\
\hline
\end{tabular}
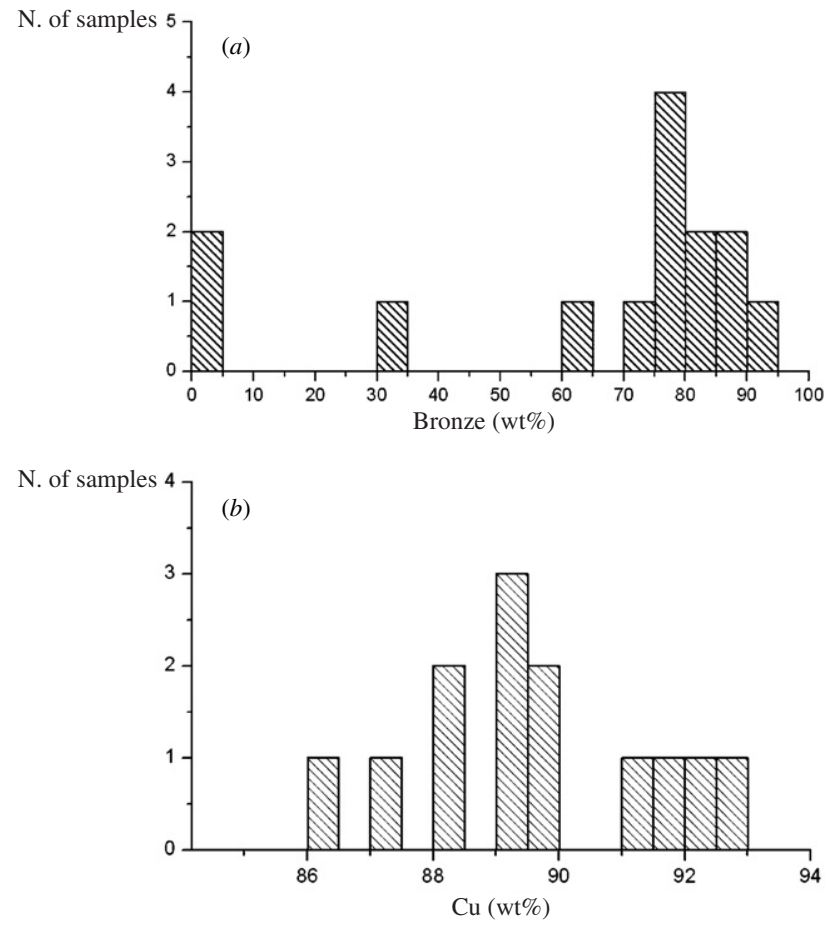

Figure 3. Histograms report results of ND analysis shown in table 1 . (a) Number of samples where a given weight percentage of bronze has been detected, $(b)$ number of samples where a given weight percentage of $\mathrm{Cu}$ in the bronze alloy has been detected.

annealing, different cooling dynamics. This information, compared to the above-mentioned diffraction results, was used to deduce the type of treatment undergone for the examined Etruscan samples. In figure 4 the relative peak width, $\Delta d / d$, has been reported as a function of $d$-spacing for all samples. Working methods for the examined Etruscan bronzes appear to be very similar, within the experimental error. A comparison with the $\Delta d / d$ behaviour of the standard samples [4,5] shows that annealing and two different types of cooling dynamics (fast and slow) are certainly present, while hammering could also have been used as a working technique.

\subsection{Neutron tomography measurements and results}

Among different techniques NT allows a close analysis of samples of archaeological interest without damaging them. In addition, it is possible to investigate thick samples

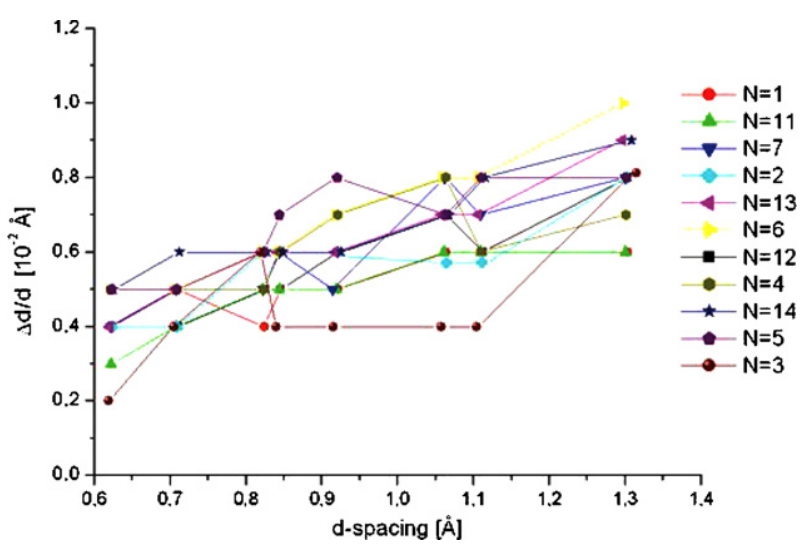

Figure 4. Relative variation of the bronze-Bragg peak widths for the different samples. Errors in $\Delta d / d$ are 0.002 . In the limits of the experimental errors, all samples present the same behaviour.

thanks to the high penetrating ability of neutrons and to investigate the spatial distribution of the components which form the samples. Tomography measurements on selected samples have been performed on CONRAD instrument at the Hahn-Meitner Institut in Berlin, Germany. The instrument provides a cold-neutron beam with wavelengths between $2 \AA$ and $12 \AA$. Two measuring positions are available: a high-flux position $(2 \times 108) \mathrm{n} \mathrm{cm}^{-2}$ and a high-resolution position. The former allows real time imaging or highspeed tomography investigations, whereas the latter allows phase-contrast tomography experiments by using the pin-hole geometry to optimize beam collimation, thus improving spatial resolution (up to $200 \mu \mathrm{m}$ ). Results of NT high-resolutionposition experiments are shown in table 2 . For each sample 300 projections were collected. The components of each sample are derived from different absorption coefficients. Because the absorption coefficient of a component arises from its chemical composition, one can virtually link each component with the corresponding phase. Moreover, imaging techniques allow identification of the spatial distribution of the components (figure 5). The comparison between NT and ND results shows that the two techniques yield values of composition in good agreement for samples 7,12 and 14; in fact, it is shown that the number of components found through NT is equal to the number of phases found through ND (see table 2). Sample 8, despite the poor agreement between NT and ND, is interesting because it shows a large homogeneous area with an inclusion 

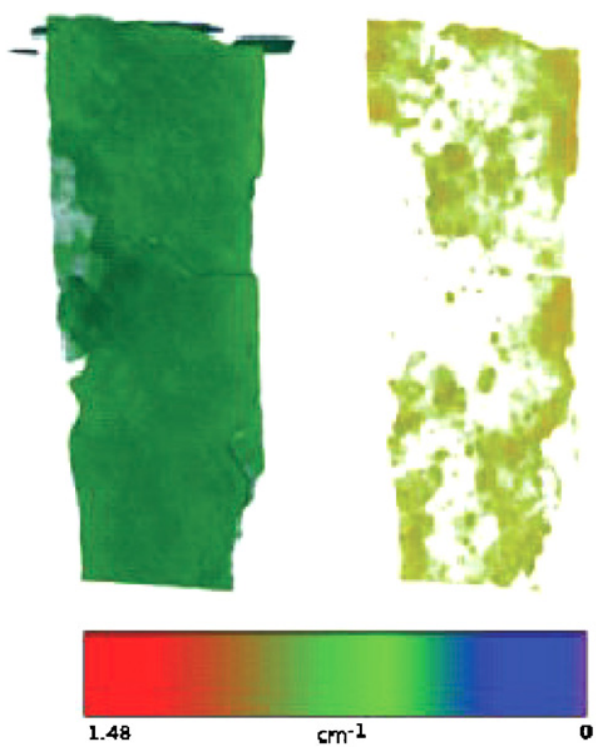

Figure 5. Tomographic reconstruction of sample 7 (left), the same image from which one of the components has been erased (right).

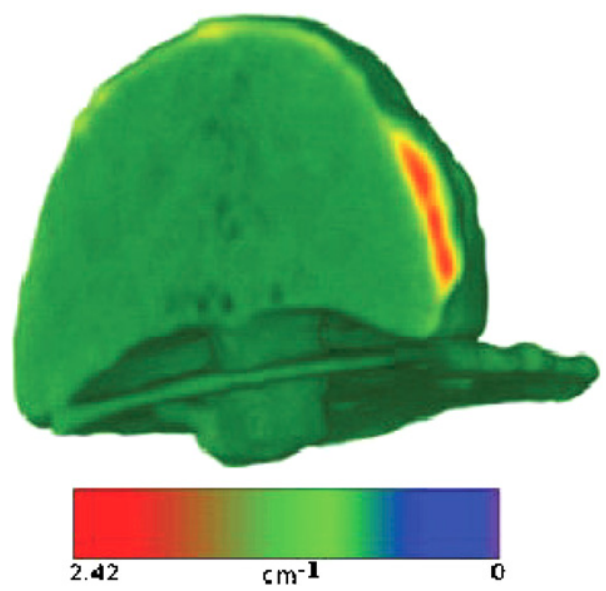

Figure 6. Tomographic reconstruction of sample 8; the inclusion with high attenuation coefficient on the edge is clearly visible.

on its edge (figure 6); further investigation will be necessary to provide the chemical composition of this sample.

\section{Corrosion environments}

Generally speaking, atmospheric corrosion is an important degradation process which causes damage to equipment and structures. It has become evident that acid deposition through rain, snow, fog or dew has resulted in substantial deterioration of artistic and historical objects, including ancient buildings and structures of historic value, statues, monuments and other cultural heritage. The atmospheric corrosion of metals is an electrochemical process in which a metal reacts with its environment to form an oxide or other compounds. Metals exposed in the environment will absorb water forming a thin water layer on their surface. Several gases like oxygen $\left(\mathrm{O}_{2}\right)$ and pollutants-like sulphur dioxide $\left(\mathrm{SO}_{2}\right)$ and carbon dioxide
$\left(\mathrm{CO}_{2}\right)$ - which are present in larger amounts in urban and industrial environments, accelerate corrosion processes. $\mathrm{CO}_{2}$ is a colourless gas with a sharp, irritating odour. $\mathrm{SO}_{2}$ is an acidic gas and it is a major component of acid rain; because it mixes and oxidizes with water vapour in the atmosphere to produce sulphuric acid $\left(\mathrm{H}_{2} \mathrm{SO}_{4}\right), \mathrm{SO}_{2}$ influences strongly the local $\mathrm{pH}$ on the surface. This causes oxide dissolution and increases the corrosion rate. Additionally $\mathrm{CO}_{2}$, mainly formed by the combustion of organic matter, has an important role in atmospheric corrosion due to the formation of secondary products, especially on non-ferrous metals. Normally, the concentration of $\mathrm{CO}_{2}$ in the atmosphere is about $350 \mathrm{ppm}$. When dissolved in water $\mathrm{CO}_{2}$ forms carbonic acid $\left(\mathrm{H}_{2} \mathrm{CO}_{3}\right)$, a weak acid which can produce bicarbonates and carbonates, mostly insoluble. $\mathrm{CO}_{2}$ concentration is one of the most important parameters in determining corrosion processes in oil/gas production environments [1].

\section{Discussion}

The recent Fourier transform infrared spectroscopy (FTIR) studies on the effect of $\mathrm{CO}_{2}, \mathrm{SO}_{2}$ and $\mathrm{NaCl}$ concentration on atmospheric corrosion of metals may help in understanding crevice corrosion, pitting corrosion and corrosion beneath organic coating. The mechanism by which $\mathrm{CO}_{2}$ controls the corrosion of copper is well understood. It has been reported [9] that $\mathrm{CO}_{2}$ has a strong effect on the $\mathrm{NaCl}$ induced atmospheric corrosion of metals; the corrosion is considerably lower at low $\mathrm{CO}_{2}$ concentrations $\left(\left[\mathrm{CO}_{2}\right]<1 \mathrm{ppm}\right)$ than at environmental concentration $\left(\left[\mathrm{CO}_{2}\right] \approx 350 \mathrm{ppm}\right)$. At $\left[\mathrm{CO}_{2}\right]<$ $1 \mathrm{ppm}$ the $\mathrm{NaCl}$ induced corrosion leads to the formation of corrosion products containing cuprite $\left(\mathrm{Cu}_{2} \mathrm{O}\right)$, tenorite $(\mathrm{CuO})$, botallackite $\left(\mathrm{Cu}_{2}(\mathrm{OH})_{3} \mathrm{Cl}\right)$, Copper(II) hydroxide $\left(\mathrm{Cu}(\mathrm{OH})_{2}\right)$ and carbonate $\left(\mathrm{CO}_{3}\right)^{2-}$. Another factor which influences the corrosion process, is the effect of $\mathrm{CO}_{2}$ and $\mathrm{pH}$ combined. At higher $\mathrm{pH}$ values $\left(\left[\mathrm{CO}_{2}\right]<1 \mathrm{ppm}\right)$ the formation of tenorite and cuprite is favoured. The presence of tenorite increases the corrosion resistance of the oxide layer and ultimately decreases the corrosion rate. Under the same conditions it is possible to have the formation of insoluble nantockite $(\mathrm{CuCl})$, whereby more soluble chlorides have the tendency to trigger localized corrosion and to accelerate the initial atmospheric corrosion of copper. At $\left[\mathrm{CO}_{2}\right]$ close to $350 \mathrm{ppm}$, the corrosion products after exposure include cuprite, malachite $\left(\mathrm{Cu}_{2}(\mathrm{OH})_{2} \mathrm{CO}_{3}\right)$, carbonate but not tenorite. In these conditions $\mathrm{CO}_{2}$ will increase the corrosion rate of samples exposed. It has been shown [9] that the oxidation of $\mathrm{SO}_{2}$ in the presence of humidity leads to formation of sulphate $\left(\mathrm{SO}_{4}\right)^{2-}$ and dithionate $\left(\mathrm{S}_{2} \mathrm{O}_{6}\right)^{2-}$ ions. A copper catalysed reaction for the sulphite oxidation was suggested; it includes the formation of a $\mathrm{Cu}$ (II)-sulfito complex as an important step. The corrosion products finally formed are nantockite, botallackite, sulphate, sulphides and small amounts of dithionate and carbonate (figure 7). However the mechanism by which $\mathrm{SO}_{2}$ accelerates the corrosion of copper is still not fully understood.

In samples 1, 2, 3, 4, 5, 8, 9, 12 and 14 the presence of cuprite may be justified at a high level of $\left[\mathrm{CO}_{2}\right]$. For example, at $\left[\mathrm{CO}_{2}\right] \approx 350 \mathrm{ppm}$ the main corrosion product 


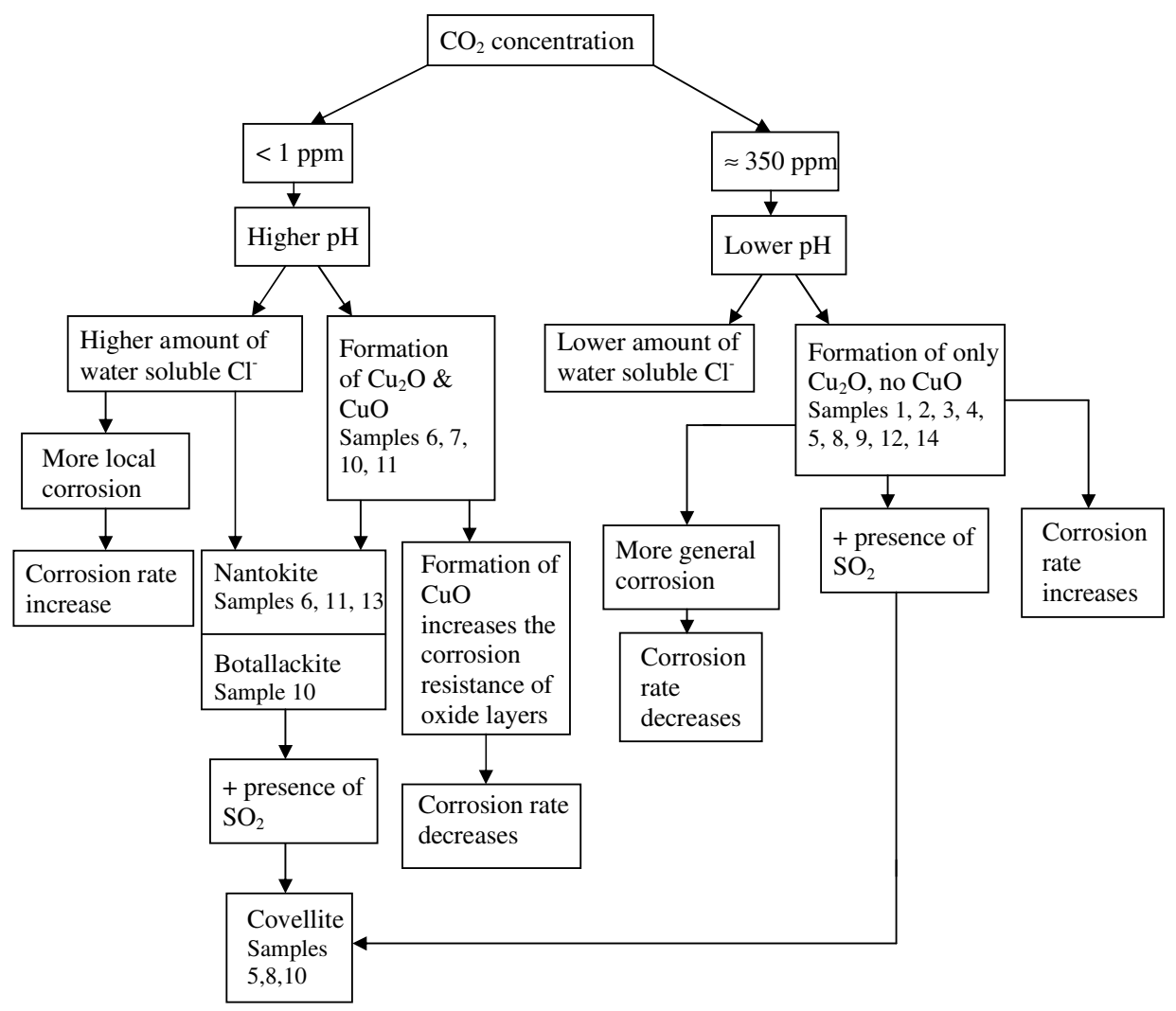

Figure 7. Schematic draft of chemical phenomena on bronze surface.

after exposure in low $\mathrm{pH}$ conditions is cuprite, which will increase the corrosion rate. Absence of chloride compounds is indicative of an essentially dry environment. In samples 5 and 8 the presence of $\mathrm{SO}_{2}$, besides the formation of a $\mathrm{Cu}$ (II)-sulfito complex, promotes the formation of copper sulphides.

A different situation is shown in samples 6, 7, 10 and 11 where the presence of tenorite implies $\left[\mathrm{CO}_{2}\right]<1 \mathrm{ppm}$ for the conservation environment. At such a concentration the high $\mathrm{pH}$ value on the surface promoted the formation of both tenorite and cuprite. The resulting layer acted as a passive surface and contributed to a lower corrosion rate. The presence of nantokite in samples 6,11 and 13 as well as of botallackite in sample 10 could be due to a higher amount of water soluble chlorides in the environment. The low quantity of chloride in comparison to other copper compounds shows that the corrosion rate decreases at low $\left[\mathrm{CO}_{2}\right](<1 \mathrm{ppm})$.

Finally, in samples 5, 8 and 10 the combination of $\mathrm{SO}_{2}$ and $\mathrm{CO}_{2}$ promotes the formation of sulphate, sulphite and sulphides (CuS in sample 10) and small amounts of dithionate and carbonate. The formation of covellite $(\mathrm{CuS})$ may be due to combination of botallackite with $\mathrm{SO}_{2}$, through the presence of intermediate states (Cu sulphates).

The presence of covellite may be indicative of contact with salted water, as it has been proven [1,9] that copper sulphide is a common corrosion product on objects buried in seawater sediments removed from oxygenated conditions.

Covellite presence also suggests burial conditions where reduction of sulphate by bacteria is possible. Sulphide ions are produced essentially by the reaction $2 \mathrm{SO}_{4}{ }^{2-} \leftrightarrow \mathrm{S}^{0}+$ $\mathrm{S}^{2-}+4 \mathrm{O}_{2}$. The bacteria utilize oxygen for oxidative enzymatic activity, and one of the end products in seawater or sediments is hydrogen sulphide $\left(2 \mathrm{H}^{+}+\mathrm{S}^{2-} \leftrightarrow \mathrm{H}_{2} \mathrm{~S}\right)$ which can form insoluble complexes with trace elements in oxygen-deficient sediments. Formation of hydrogen sulphide accelerates the corrosion of copper alloys by formation of covellite.

\section{Conclusions}

Non-destructive neutron measurements (ND and NT) provided important information about examined Etruscan artefacts.

Results for ND investigation of samples show that 60 $95 \%$ by weight is uncorroded alloy that presents a composition $(\mathrm{Cu}=90 \pm 4 \%)$ which is typical of low-tin ancient bronzes thus supporting authenticity of the samples. ND measurements also provided information about working methods of bronzes through the analysis of relative bronze peak width $\Delta d / d$ as a function of $d$-spacing: annealing and two different types of cooling dynamics (fast and slow) are present while hammering could also be present.

NT analysis provided spatial distribution of compounds within the samples. NT and ND results comparison shows that the two techniques yield values of composition in good agreement for samples 7,12 and 14. Sample 8 shows a large homogeneous area with an inclusion on its surface; further investigation is needed to identify its nature. 
Furthermore, the combination of corrosion products in each sample can be related to possible environmental conditions in which the objects were in contact. Most of the samples were buried. Some of these were in contact with salted water. This could come from seawater percolation or simply salted food contained in the vases. Furthermore, it has been possible to trace likely quantitative values for the concentration of certain environmental components such as $\mathrm{CO}_{2}$ and $\mathrm{NaCl}$ present in the tombs.

\section{Acknowledgments}

The work done at ISIS was supported within the CNRCCLRC Agreement No. 01/9001 concerning collaboration in scientific research at the spallation neutron source ISIS. The financial support of the CNR is hereby acknowledged. For the work done at BENSC we also acknowledge support from the European Commission under the 6th Framework Programme through the Key Action: Strengthening the European Research Area, Research Infrastructures. Contract no: RII3-CT-2003-505925 (NMI3). Collaboration with C Palazzesi, Department of Physics, Università degli Studi di Roma 'Tor Vergata', for the investigation with photomicrographs is gratefully acknowledged.

\section{References}

[1] Scott D A 2002 Copper and bronze Art. Corrosion, Colorants, Conservation (Los Angeles: The Getty Conservation Institute)

[2] Sestini A 1979 Introduzione all'Etruria mineraria: il quadro naturale e ambientale Proc. Meeting of Etruscan Study and Italic (Florence) 'L'Etruria Mineraria'

[3] Zifferero A 1991 Miniere e metallurgia estrattiva in Etruria meridionale. Per una lettura critica di alcuni dati archeologici e minerari, StEtr 57

[4] Siano S, Kockelmann W, Bafile U, Celli M, Iozzo M, Miccio M, Moze O, Pini R, Salimbeni R and Zoppi M 2002 Appl. Phys. A 74 S1139-42

[5] Siano S, Bartoli L, Santisteban J R, Kockelmann W, Daymond M R, Miccio M and De Marinis G 2006 Archaeometry 48 77-96

[6] Larson A C and Von Dreele R B 2000 General structure analysis system (GSAS) Los Alamos National Laboratory Report LAUR 86-748

[7] Toby B H 2001 EXPGUI, a graphical user interface for GSAS J. Appl. Cryst. 34 210-3

[8] Fletcher D A, McMeeking R F and Parkin F 1996 J. Chem. Inf. Comput. Sci. 36 746-9

[9] Chen C Y 2005 The role of particles on initial atmospheric corrosion of copper and zinc Doctoral Thesis ISBN 91-7178-155-2 Royal Institute of Technology, Stockholm 